REPORTS OF MORPHOLOGY
$\begin{gathered}\text { Official Journal of the Scientific Society of Anatomists, } \\ \text { Histologists, Embryologists and Topographic Anatomists } \\ \text { of Ukraine } \\ \text { journal homepage: https://morphology-journal.com }\end{gathered}$

\title{
Morphological changes in the conditions of adrenaline myocardial dystrophy against the background of the introduction of the compound PC-66 and amiodarone to rats
}

\author{
Dzhyhaliuk O.V., Lysenko D.A., Smolko D.G., Kyrychenko I.M., Prokopenko S.V. \\ National Pirogov Memorial Medical University, Vinnytsya, Ukraine
}

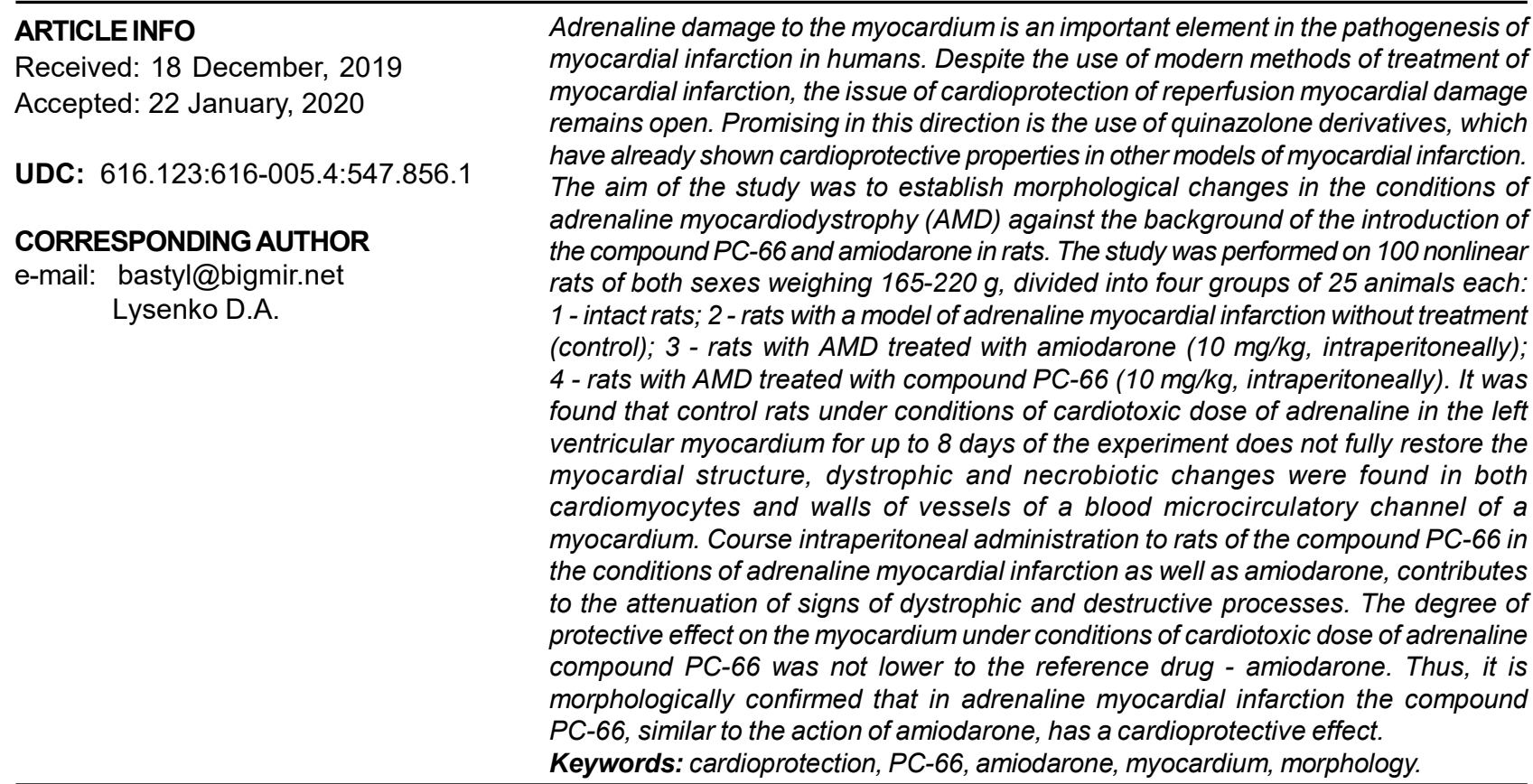

\section{Introduction}

Adrenaline myocardial damage is an important element in the pathogenesis of myocardial infarction in humans, which can be both an inducer of the pathological process and part of cascading myocardial damage $[12,18]$. It has been established $[1,10]$ that myocardial infarction in humans causes significant endothelial injury, as well as a parallel increase in the concentration of circulating catecholamines and, in particular, adrenaline. It was also found [3] that sympatho-adrenal activation is a standard response of the body to myocardial infarction, but it can turn from a protective reaction to non-adaptive, which, in turn, can contribute to myocardial damage with a direct negative impact on the endothelium. There is no doubt that circulating catecholamines and endothelial damage are interrelated and lead to increased mortality after myocardial infarction [9]. Despite the use of modern methods of treatment, myocardial infarction remains an open issue of cardioprotection of reperfusion myocardial damage [2].

Cardioprotection in myocardial infarction is a very significant factor influencing the consequences of therapy and survival of patients despite the use of thrombolysis [7]. Insufficient efficiency and the presence of side (negative) reactions in modern cardioprotective agents encourage the search for new molecules with this effect, promising to create on their basis more effective and safe drugs [9]. The search for new drugs is carried out around the world and includes both the study of the protective properties of longknown substances [8] and the study of new synthesized 
substances with potential protective activity [5, 15]. According to many researchers $[16,22]$, the second way is more promising in scientific and practical terms.

In our opinion, the use of quinazolone derivatives, which have already shown cardioprotective properties [6] in other models of myocardial infarction, is promising in this direction.

That is why in order to establish the characteristics of the cardioprotective activity of the compound PC-66 we chose an experimental model of myocardial ischemia adrenaline myocardiodystrophy (AMD) [14], which will reveal the cardioprotective effect of this compound. For comparison, we used amiodarone, which is currently considered by many researchers $[11,23]$ as a reference drug with cardioprotective properties against the background of myocardial infarction. It is also important to note that we studied the morphological changes that are the most objective signs of myocardial damage and its recovery against the background of treatment $[13,15]$.

Purpose of study: to establish morphological changes in the conditions of adrenaline myocardial infarction on the background of the introduction of the compound PC-66 and amiodarone in rats.

\section{Materials and methods}

AMD was modeled according to the standard method [15] by a single intramuscular (intravenous) injection of $0.18 \%$ solution of adrenaline tartrate (PJSC Pharmaceutical Company "Darnytsia", Kyiv) at a dose of $1 \mathrm{mg} / \mathrm{kg}$ body weight. The study was performed on 75 nonlinear rats of both sexes weighing $165-220 \mathrm{~g}$, divided into four groups of 25 animals each: 1 - intact rats; 2 - rats with AMD model without treatment (control); 3 - rats with AMD receiving amiodarone $(10 \mathrm{mg} / \mathrm{kg}$, intraperitoneally (i/p)); 4 - rats with AMD, receiving compound PC-66 (10 mg/kg, i/p). The test substances were administered to groups of animals daily for 7 days: the first injection - for 30 minutes before AMD modeling.

Committee on Bioethics of National Pirogov Memorial Medical University, Vinnytsya (Minutes №7 from 21.09.2018) found that the experiment was conducted considering the recommendations of the European Commission for medical and biological research using animals, medical recommendations of the State Pharmacological Center of the Ministry of Health of Ukraine, as well as "Rules for clinical safety assessment pharmacological agents (GLP)".

To assess the morphological changes in the myocardium of experimental animals under experimental ischemia using PC-66 and reference drugs, pieces of cardiac muscle were fixed in $10 \%$ neutral formalin solution. Micropreparations were prepared according to standard methods, histological sections 5-7 $\mu \mathrm{m}$ thick were stained with hematoxylin and eosin, picrofuxin according to Van Gieson, a combination of PAS reaction with alcian blue [21].

Microscopy and photographing of histological specimens were performed using a light microscope OLIMPUS BX-41 at magnifications of $40,100,200,400$ and 1000 times.

\section{Results}

Microscopic examination revealed that in control rats under conditions of cardiotoxic dose of adrenaline in the left ventricular myocardium on the second day of the experiment there is damage to the walls of blood vessels of the circulatory microcirculatory system, which lead to cardiac hemodynamics and reversible and irreversible structural changes. Under the conditions of action of a cardiotoxic dose of adrenaline in a myocardium of a left ventricle of rats in the specified term of experiment of a gleam of arterioles were full-blooded and contained parietal thrombi. In the walls of arterioles endothelial cells in a state of edema and destructively altered, do not form a continuous layer. In venules the gleams are expanded, sharply full-blooded. Endotheliocytes in their walls are also dystrophically and necrobiotically altered. Such changes increase the permeability of the walls of the vessels of the blood microcirculatory tract in the myocardium of the left ventricles of rats with the development of perivascular edema, hemorrhage and histiolymphocytic infiltration (Fig. 1).

On the 8th day of the experiment under the action of a cardiotoxic dose of adrenaline, morphological disorders in the myocardium of rats were more pronounced than in the previous period of the study. During this period, dystrophic, hypertrophic and necrobiotic processes that developed in the myocardium were unbalanced and disproportionate. We found the predominance of dystrophic changes in cardiomyocytes. Histological examination revealed parenchymal dystrophy with pyknosis of the nuclei in cardiomyocytes.

Fibroblast proliferation is present around the muscle fibers, indicating connective tissue growth. Arterioles in the myocardium showed signs of spasm and histiolymphocytic infiltration of the walls. At the same time, hypertrophied cardiomyocytes were almost absent (Fig. 2).

By the 8th day of the experiment there is no complete restoration of the structure of the myocardium of experimental rats, dystrophic and necrobiotic changes were detected in both cardiomyocytes and vascular walls of the blood microcirculatory tract of the myocardium.

Against the background of amiodarone, areas of the myocardium with signs of cardiomyocyte alteration were detected less frequently than in control rats. In most cardiomyocytes, the transverse striation is preserved, in contrast to rats, which were administered adrenaline without correction (Fig. 3). Foci of cardiomyocyte necrosis usually contained one cell and were not detected in all fields of vision.

The lumens of the blood capillaries are dilated, moderately full-blooded, but the endothelial lining of the capillaries is intact. The basement membrane in the walls 


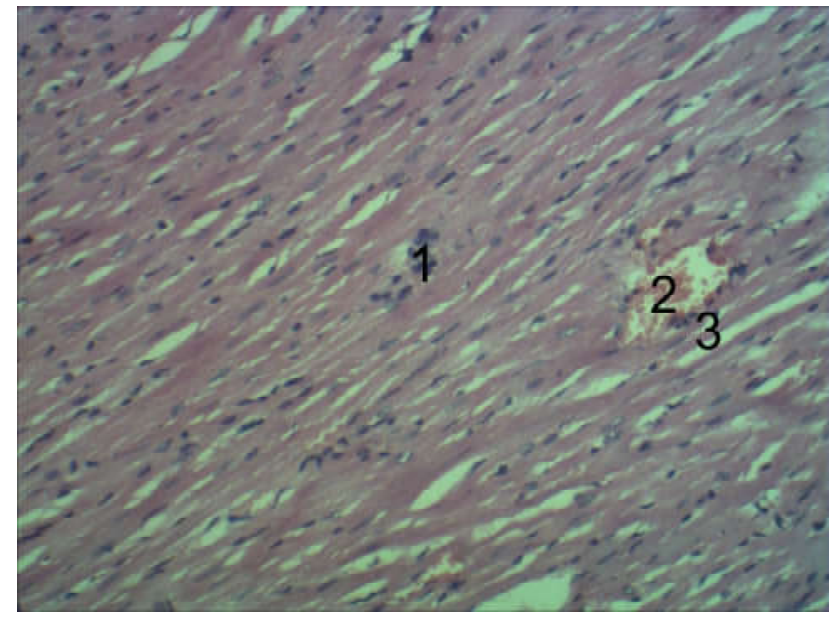

Fig. 1. A fragment of the myocardium of rats which was administered the compound PC-66 to correct the action of adrenaline. 2 day of observation. 1 - focal necrosis of cardiomyocytes; 2 - dilated lumens of the venules; 3 - stasis and diapedesis of leukocytes through the walls of venules. Hematoxylin-eosin. x100.

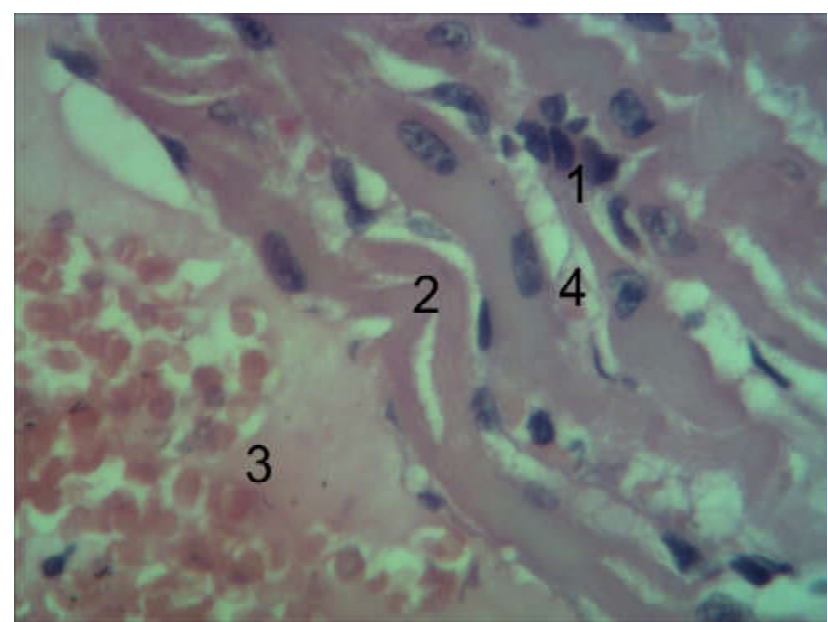

Fig. 3. A fragment of the myocardium of the left ventricle of a rat which was administered amiodarone to correct the action of adrenaline. 2 day of observation. 1 - cardiomyocyte necrosis; 2 shortened cardiomyocytes; 3 - dilated and full-blooded lumens of the venules; 4 - dilated lumens of blood capillaries. Hematoxylineosin. $x 400$.

of blood capillaries is homogeneous in thickness and color. At the same time, no diapedesis hemorrhages were detected. The interstitium around the capillaries is not loose, without signs of edema and contained single lymphocytes.

On day 8 of the experiment, rats treated with Cordarone were less likely to show signs of dystrophic and alterative changes in the left ventricular myocardium, both in cardiomyocytes and in the vessel walls of the blood microcirculatory tract, compared with control rats of the same research period (Fig. 4). Thus, in most of the cardiomyocytes of rats, which were administered Cordarone on the background of the action of adrenaline, there is a transverse striation, and the sarcoplasm was stained moderately basophilic. The endothelial lining in the walls of arterioles

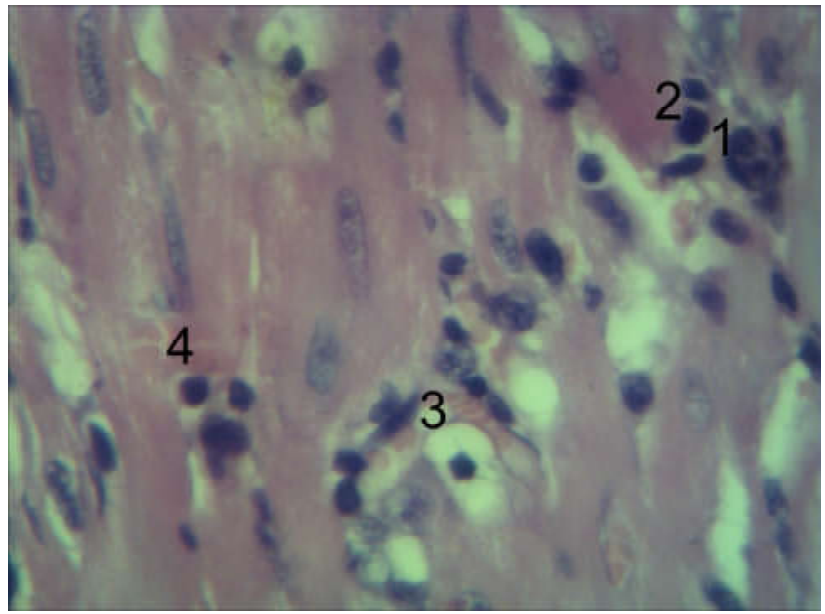

Fig. 2. Fragment of the myocardium of the left ventricle of rats on the background of the action of adrenaline for 8 days (control). 1 - focal necrosis of cardiomyocytes; 2 - histiolymphocytic infiltration; 3 - dilated full-blooded lumens of blood capillaries; 4 - full-blooded lumens of venules. Hematoxylin-eosin. x400.

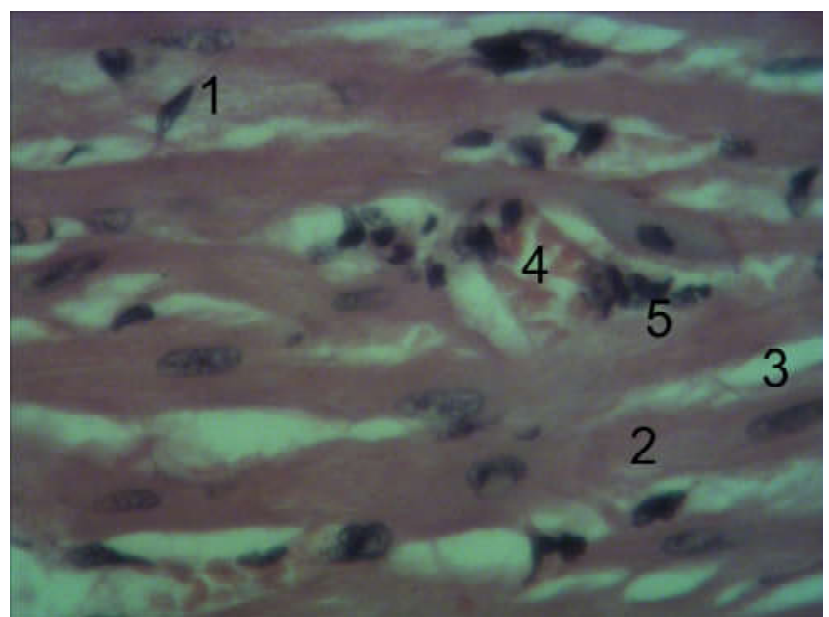

Fig. 4. A fragment of the myocardium of rats which was administered amiodarone to correct the action of adrenaline. 8 days of observation. 1 - dystrophically altered cardiomyocytes; 2 - muscle fibers; 3 - blood capillaries; 4 - venules; 5 - stasis and diapedesis of leukocytes through the walls of venules. Hematoxylineosin. $x 400$.

and venules is continuous. Thrombi in arterioles and venules were found less frequently in contrast to rats given adrenaline without correction. The lumens of the venules and blood capillaries are dilated and moderately full-blooded compared to those in intact rats.

When using the compound PC-66 to correct the effect of adrenaline on the myocardium of rats at all times of the study, pathological changes in its structure are less pronounced than in rats that were administered adrenaline without correction (Fig. 5).

In most cardiomyocytes, the transverse striation was preserved. The foci of cardiomyocytes, in the sarcoplasm of which there is no transverse striation, as well as areas of shortened cardiomyocytes, are smaller than in rats, which were administered adrenaline without correction. Foci of 


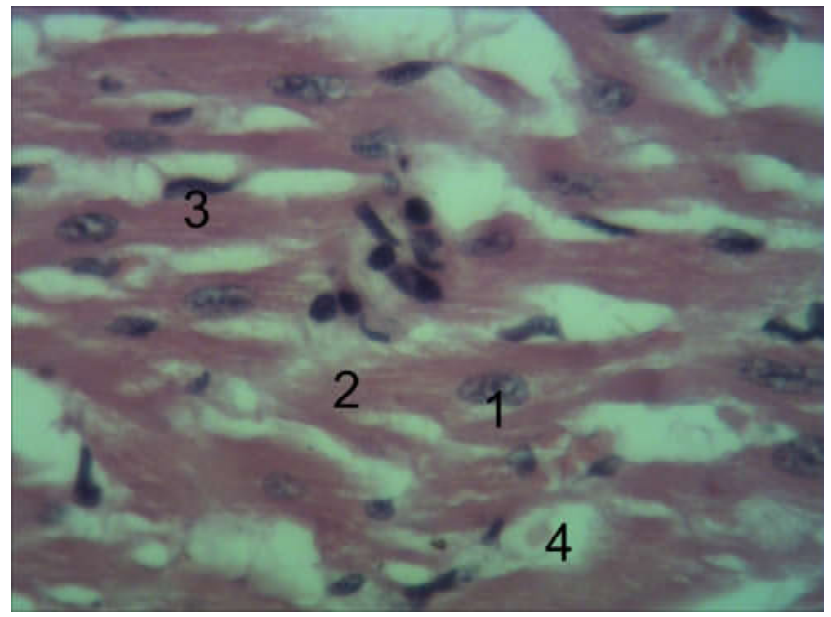

Fig. 5. A fragment of the myocardium of rats which was administered the compound PC-66 to correct the action of adrenaline. 2 day of observation. 1 - nuclei of cardiomyocytes; 2 sarcoplasm of cardiomyocytes; 3 - fibroblasts; 4 - dilated lumens of capillaries. Hematoxylin-eosin. x400.

cardiomyocyte necrosis usually contained one cell and were not detected in all fields of view. Hypertrophied cardiomyocytes are located around the foci of necrotic cardiomyocytes, but their number was higher than in rats treated with Cordarone to correct the action of adrenaline. Areas of the myocardium with signs of cytoplasmic dystrophy and cardiomyocyte alteration were found less frequently than in rats treated with uncorrected adrenaline.

On day 8 of the study, rats treated with PC-66 for adrenaline showed signs of dystrophic and necrobiotic changes in the left ventricular myocardium, both in cardiomyocytes and in the vascular walls of the circulatory microcirculatory system, similar to those in rats. Corrections of the cardiotoxic effect of adrenaline were similar to administered Cordarone, and less pronounced than in rats administered adrenaline without correction in the same period of the study.

Left ventricular myocardial cardiomyocytes had the same diameter and shape. In the sarcoplasm of most of the cardiomyocytes of rats, which on the background of the action of adrenaline was administered the compound $\mathrm{PC}-66$, there is a characteristic transverse striation. The nuclei in cardiomyocytes are located in the center, oval, chromatin in them is clarified in the center and condensed on the periphery (Fig. 6).

The endothelial lining in the walls of arterioles and venules is continuous. Thrombi in arterioles and venules were not detected in all fields of view, in contrast to rats, which were administered adrenaline without correction. The lumens of the venules and blood capillaries are dilated and moderately full-blooded compared to those in intact rats.

\section{Discussion}

Thus, the results of the study showed that the course of intraperitoneal administration to rats of the compound

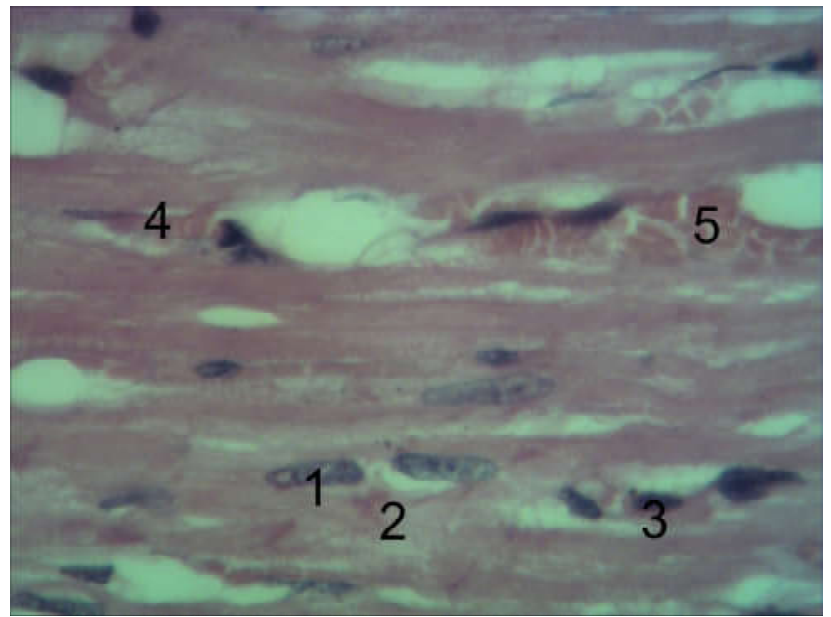

Fig. 6. A fragment of the myocardium of rats which was administered the compound PC-66 to correct the action of adrenaline. 8 days of observation. 1 - nuclei of cardiomyocytes; 2 - sarcoplasm of cardiomyocytes; 3 - proliferation of fibroblasts, 4 - dilated lumens of capillaries; 5 - dilated lumens of the venules. Hematoxylin-eosin. $x 400$.

PC-66 at a dose of $10 \mathrm{mg} / \mathrm{kg}$ in conditions of adrenaline myocardiodystrophy as well as amiodarone $(10 \mathrm{mg} / \mathrm{kg}$ $\mathrm{i} / \mathrm{p})$, helps to reduce the symptoms of degenerative and destructive processes [21] in damaged heart muscle, which may be a sign of the presence of cardioprotective action in the studied quinazoline derivative under given experimental conditions, and similar in other studies of cardioprotective properties [2,6]. The degree of protective effect on the myocardium under conditions of cardiotoxic dose of adrenaline compound PC-66 was not inferior to the reference drug - amiodarone, which is a recognized cardioprotector $[11,23]$ in myocardial infarction.

The obtained results also indicate a significant damaging effect of adrenaline, which is realized on both the 2nd and 8th day of the study, which indicates a longterm negative effect of this compound $[12,18]$. The injuries were not corrected without the use of cardioprotection, which increases the risk of further mortality in clinical practice [10].

The use of PC-66, as well as the comparison drug helped to reduce the degree and prevalence of pathological changes in the myocardium caused by experimental ischemia. Myocardial remodeling that occurs after an episode of ischemic injury has one very important aspect the reconstruction of the connective tissue framework [19]. This develops enzymatic cleavage of connective tissue fibers (mainly collagen) and the synthesis of an intermediate substance, according to the new conditions of mechanical loads on the organ [4]. The greatest role in this process is assigned to enzymes of the metalloprotease group [20]. By the end of the experiment in animals treated with PC-66, changes in the myocardium were minimal, the histological structure of the heart muscle was close to that in the intact group. There were no signs of inflammation and severe circulatory disorders. Note that in comparison 
with the intact myocardium there is a slight increase in the width of the stromal spaces and the diameter of cardiomyocytes, which indicates [17] the preservation of intercellular and intracellular edema, but these pathomorphological changes in the interstitium and cardiomyocytes are not alterative.

The use of PC-66 and amiodarone caused similar morphological changes in the myocardium, which indicate increased regeneration and reduced damage of adrenaline $[15,21]$. The obtained changes indicate a direct cardioprotective effect of amiodarone and PC-66 on the background of AMD set at the morphological level according to modern recommendations [3].

\section{References}

[1] Alvarez-Diduk, R., \& Galano, A. (2015). Adrenaline and noradrenaline: protectors against oxidative stress or molecular targets? The Journal of Physical Chemistry B, 119(8), 34793491. doi: 10.1021/acs.jpcb.5b00052

[2] Boarescu, P. M., Boarescu, I., Bocşan, I. C., Pop, R. M., Gheban, D., Bulboacă, A. E., ... \& Bolboacă, S. D. (2019). Experimental model of acute myocardial infarction for evaluation of prevention and rehabilitation strategies in cardiovascular diseases - A pilot study. Balneo Res. J, 10, 288-293. doi: 10.12680/balneo.2019.270

[3] B?tker, H. E., Hausenloy, D., Andreadou, I., Antonucci, S., Boengler, K., Davidson, S. M., ... \& Efentakis, P. (2018). Practical guidelines for rigor and reproducibility in preclinical and clinical studies on cardioprotection. Basic research in cardiology, 113(5), 39. doi: 10.1007/s00395-018-0696-8

[4] Buchholz, B., Donato, M., Perez, V., Deutsch, A. C. R., H?cht, C., Del Mauro, J. S., ... \& Gelpi, R. J. (2015). Changes in the loading conditions induced by vagal stimulation modify the myocardial infarct size through sympathetic-parasympathetic interactions. Pflügers Archiv-European Journal of Physiology, 467(7), 1509-1522. doi: 10.1007/s00424-014-1591-2

[5] Davidson, S. M., Arjun, S., Basalay, M. V., Bell, R. M., Bromage, D. I., Bøtker, H. E., ... Yellon, D. M. (2018). The 10th Biennial Hatter Cardiovascular Institute workshop: cellular protectionevaluating new directions in the setting of myocardial infarction, ischaemic stroke, and cardio-oncology. Basic Res. Cardiol., 113(6), 43. doi: 10.1007/s00395-018-0704-z

[6] Dzhyhaliuk, O. V., Stepanyuk, G. I., Shabelnik, K. P., Kovalenko, S. I., \& Pashinskaya, O. S. (2019). Cardioprotective activity and screening in a series of $\mathrm{N}$-substituted quinazolin- $4(3 \mathrm{H})$ ones. Zaporizhzhya Medical Journal, 21(1), 112-117. doi: 10.14739/2310-1210.2019.1.155852

[7] Eitel, I., Stiermaier, T., Rommel, K. P., Fuernau, G., Sandri, M., Mangner, N., ... Mende, M. (2015). Cardioprotection by combined intrahospital remote ischaemic perconditioning and postconditioning in ST-elevation myocardial infarction: the randomized LIPSIA CONDITIONING trial. European Heart Journal, 36(44), 3049-3057. doi: 10.1093/eurheartj/ehv463

[8] Hausenloy, D. J., Garcia-Dorado, D., Bøtker, H. E., Davidson, S. M., Downey, J., Engel, F. B., ... Ferdinandy, P. (2017). Novel targets and future strategies for acute cardioprotection: Position Paper of the European Society of Cardiology Working Group on Cellular Biology of the Heart. Cardiovascular Research, 113(6), 564-585. doi: 10.1093/cvr/cvx049

[9] Heusch, G. (2015). Molecular basis of cardioprotection: signal transduction in ischemic pre-, post-, and remote conditioning.

\section{Conclusions}

1. The administration to rats of the compound PC-66 at a dose of $10 \mathrm{mg} / \mathrm{kg}$ in conditions of adrenaline myocardial infarction as well as amiodarone $(10 \mathrm{mg} / \mathrm{kg} \mathrm{i} / \mathrm{p})$, helps to reduce the symptoms of degenerative and destructive processes in the damaged heart muscle, which can be a sign of the presence of cardioprotective action in the investigated quinazoline derivative under given experimental conditions.

2 According to the degree of protective effect on the myocardium in the conditions of cardiotoxic dose of adrenaline, the compound PC-66 was not lower to the reference drug.

Circulation Research, 116(4), 674-699. doi: 10.1161/ CIRCRESAHA.116.305348

[10] Johansson, P. I., Bro-Jeppesen, J., Kjaergaard, J., Wanscher, M., Hassager, C., \& Ostrowski, S. R. (2015). Sympathoadrenal activation and endothelial damage are inter correlated and predict increased mortality in patients resuscitated after outof-hospital cardiac arrest. a post Hoc sub-study of patients from the TTM-trial. PLoS One, 10(3), e0120914. doi: 10.1371/ journal.pone.0120914

[11] Kapur, N. K., Alkhouli, M. A., DeMartini, T. J., Faraz, H., George, Z. H., Goodwin, M. J., ... Kaki, A. (2019). Unloading the left ventricle before reperfusion in patients with anterior STsegment-elevation myocardial infarction: a pilot study using the Impella CP. Circulation, 139(3), 337-346. doi: 10.1161/ CIRCULATIONAHA.118.038269

[12] Kim, Y. H., Nijst, P., Kiefer, K., \& Tang, W. W. (2017). Endothelial glycocalyx as biomarker for cardiovascular diseases: mechanistic and clinical implications. Current heart failure reports, 14(2), 117-126. doi: 10.1007/s11897-017-0320-5

[13] Ko, B., Drakos, S. G., Ibrahim, H., Kang, T. S., Thodou, A., Bonios, M., ... Welt, F. G. (2020). Percutaneous mechanical unloading simultaneously with reperfusion induces increased myocardial salvage in experimental acute myocardial infarction. Circulation: Heart Failure, 13(1), e005893. doi: 10.1161/ CIRCHEARTFAILURE.119.005893

[14] Kumar, M., Kasala, E. R., Bodduluru, L. N., Dahiya, V., Sharma, D., Kumar, V., \& Lahkar, M. (2016). Animal models of myocardial infarction: mainstay in clinical translation. Regulatory Toxicology and Pharmacology, 76, 221-230. doi: 10.1016/ j.yrtph.2016.03.005

[15] Lindsey, M. L., Bolli, R., Canty Jr, J. M., Du, X. J., Frangogiannis, N. G., Frantz, S., ... Lefer, D. J. (2018). Guidelines for experimental models of myocardial ischemia and infarction. American Journal of Physiology-Heart and Circulatory Physiology, 314(4), H812-H838. doi: 10.1152/ ajpheart.00335.2017

[16] Liu, N. B., Wu, M., Chen, C., Fujino, M., Huang, J. S., Zhu, P., \& $\mathrm{Li}, \mathrm{X}$. K. (2019). Novel molecular targets participating in myocardial ischemia-reperfusion injury and cardioprotection. Cardiol. Res. Pract., 2019, 1-16 6935147. doi: 10.1155/2019/ 6935147

[17] Michaud, K., Basso, C., d'Amati, G., Giordano, C., Kholová, I., Preston, S. D., ..., van der Wal A. C. (2020). Diagnosis of myocardial infarction at autopsy: AECVP reappraisal in the light of the current clinical classification. Virchows Arch., 476(2), 179-194. doi: 10.1007/s00428-019-02662-1 
[18] Ostrowski, S. R., Pedersen, S. H., Jensen, J. S., Mogelvang, R., \& Johansson, P. I. (2013). Acute myocardial infarction is associated with endothelial glycocalyx and cell damage and a parallel increase in circulating catecholamines. Critical Care, 17(1), R32. doi: 10.1186/cc12532

[19] Parviz, Y., Waleed, M., Vijayan, S., Adlam, D., Lavi, S., Al Nooryani, A., ... Stone, G. W. (2019). Cellular and molecular approaches to enhance myocardial recovery after myocardial infarction. Cardiovascular Revascularization Medicine, 20(4), 351-364. doi: 10.1016/j.carrev.2018.05.021

[20] Takawale, A., Fan, D., Basu, R., Shen, M., Parajuli, N., Wang, W., ... Kassiri, Z. (2014). Myocardial recovery from ischemiareperfusion is compromised in the absence of tissue inhibitor of metalloproteinase 4. Circulation: Heart Failure, 7(4), 652662. doi: $10.1161 /$ CIRCHEARTFAILURE.114.001113

[21] Valentin, J., Frobert, A., Ajalbert, G., Cook, S., \& Giraud, M. N. (2016). Histological Quantification of Chronic Myocardial Infarct in Rats. JoVE (Journal of Visualized Experiments), (118), e54914. doi: 10.3791/54914

[22] Wang, J., Toan, S., \& Zhou, H. (2020). New insights into the role of mitochondria in cardiac microvascular ischemia/ reperfusion injury. Angiogenesis, 2020. doi: 10.1007/s10456020-09720-2

[23] Zaidel, E. J. (2019). Amiodarone: updated review of its current usefulness. Arch. Clin. Exp. Cardiol., 1(1), 102.

\section{МОРФОЛОГІЧНІ ЗМІНИ В УМОВАХ АДРЕНАЛІНОВОЇ МІОКАРДІОДИСТРОФІЇ НА ФОНІ ВВЕДЕННЯ СПОЛУКИ ПК-66 ТА АМІОДАРОНУ У ЩУРІВ \\ Джиеалюк О.В., Лисенко Д.А., Смолко Д.Г., Кириченко І.М., Прокопенко С.В.}

Адреналінове ушкодження міокарда є важливим елементом патогенезу розвитку інфаркту міокарда у людини. Незважаючи на застосування сучасних методик лікування інфраркту міокарда залишається відкритим питання кардіопротекції реперфузійного ушкодження міокарда. Перспективним у цьому напрямі є використання похідних хіназолону, що вже виявили кардіопротективні властивості на інших моделях інфраркту міокарда. Мета роботи - встановити морфологічні зміни в умовах адреналінової міокардіодистрофрії (АМД) на фооні введення сполуки ПК-66 та аміодарону у щурів. Дослідження проведено на 100 нелінійних щурах обох статей масою тіла 165-220 г, розбитих на чотири групи по 25 тварин у кожній: 1 - інтактні щури; 2 - щури з моделлю адреналінової міокардіодистрофрії без лікування (контроль); 3 - щури з АМД, ліковані аміодароном (10 ме/ке, внутрішньоочеревинно); 4 - щури з АМД, ліковані сполукою ПК-66 (10 ме/ке, внутрішньоочеревинно). Встановлено, що у контрольних щурів в умовах дії кардіотоксичної дози адреналіну в міокарді лівого шлуночка в термін до 8 доби експерименту не відбувається повного відновлення структури міокарда, дистрофрічні та некробіотичні зміни виявляли як в кардіоміоцитах, так і в стінках судин кровоносного мікроциркуляторного русла міокарда. Курсове внутрішньоочеревинне введення щурам сполуки ПК-66 в умовах адреналінової міокардіодистрофрії так само, як $і$ аміодарону, сприяє послабленню ознак дистрофрічних та деструктивних процесів. При цьому за ступенем захисного ефекту на міокард в умовах дії кардіотоксичної дози адреналіну сполука ПК-66 не поступалась рефреренс-препарату - аміодарону. Таким чином, морфологічно підтверджено, що при адреналіновій міокардіодистрофрії сполука ПК-66 аналогічно дії аміодарону проявляє кардіопротекторний ефект.

Ключові слова: кардіопротекція, ПК-66, аміодарон, міокард, морфологія.

\section{МОРФОЛОГИЧЕСКИЕ ИЗМЕНЕНИЯ В УСЛОВИЯХ АДРЕНАЛИНОВОЙ МИОКАРДИОДИСТРОФИИ НА ФОНЕ ВВЕДЕНИЯ СОЕДИНЕНИЯ ПК-66 И АМИОДАРОНА У КРЫС \\ Джигалюк О.В., Лысенко Д.А., Смолко Д.Г., Кириченко И.М., Прокопенко С.В.}

Адреналиновое повреждения миокарда является важным элементом патогенеза развития инфаркта миокарда у человека. Несмотря на применение современных методик лечения инфаркта миокарда остается открытым вопросом кардиопротекция реперфузионного повреждения миокарда. Перспективным в этом направлении является использование производных хиназолона, которые уже проявили кардиопротекторные свойства на других моделях инфраркта миокарда. Цель работы - установить морфологические изменения в условиях адреналиновой миокардиодистрофрии (АМД) на фоне введения соединения ПК-66 и амиодарона у крыс. Исследование проведено на 100 нелинейных крысах обоего пола массой тела 165-220 г, разбитых на четыре группы по 25 животных в каждой: 1 - интактные крысы; 2 - крысы с моделью адреналиновой миокардиодистрофии без лечения (контроль); 3 - крысы с АМД, леченные амиодароном (10 мг/кг, внутрибрюшинно); 4 - крысы с АМД, леченные соединением ПК-66 (10 ме/ке, внутрибрюшинно). Установлено, что у контрольных крыс в условиях действия кардиотоксической дозы адреналина в миокарде левого желудочка в срок до 8 суток эксперимента не происходит полного восстановления структуры миокарда, дистрофические и некробиотические изменения выявляли как в кардиомиоцитах, так и в стенках сосудов кровеносного микроциркуляторного русла миокарда. Курсовое внутрибрюшинное введение крысам соединения ПК-66 в условиях адреналиновой миокардиодистрофии так же, как и амиодарона, способствует ослаблению признаков дистрофических и деструктивных процессов. При этом по степени защитного эффректа на миокард в условиях действия кардиотоксической дозы адреналина соединение ПК-66 не уступало рефреренс-препарату - амиодарону. Таким образом, морфологически подтверждено, что при адреналиновой миокардиодистрофии соединение ПК-66 аналогично действию амиодарона проявляет кардиопротекторный эфрфект. Ключевые слова: кардиопротекция, ПК-66, амиодарон, миокард, морфология. 